\title{
Critical skills and knowledge to succeed in the township liquor retail industry
}

\author{
Andiswa P Mrasi \\ Roger B Mason \\ Albertina Jere \\ Cape Peninsula University of Technology, Cape Town, South Africa.
}

\section{Keywords}

Skills, Knowledge, Critical success factors (CSFs), Liquor retailing

\begin{abstract}
The township market makes the largest contribution to liquor sales in South Africa, but growth, sustainability and success of this market is unsatisfactory. The sector needs assistance to improve their performance. This paper aims at identifying the critical skills and knowledge specific to township liquor retailing.

Data was collected through qualitative semi-structured interviews; participants included representatives from provincial government, the top three liquor manufacturers and distributors, and forty liquor retail owners from Khayelitsha and Mitchell's Plain townships.

The findings reveal that skills and knowledge (customised to suit township are the foundation for better management of these businesses). The critical skills and knowledge are Operating Capital, Operations Management and Human Resource. Township liquor retailers fail as a result of mistakes that could be avoided through acquiring the right skills and knowledge. The current government and supplier skills and knowledge programmes should be improved and tailored to suit the profile of these entrepreneurs.
\end{abstract}

Corresponding author: Andiswa P Mrasi

Email addresses for corresponding author: mrasia@cput.ac.za

First submission received: $16^{\text {th }}$ August 2017

Revised submission received: $25^{\text {th }}$ September 2017

Accepted: $26^{\text {th }}$ October 2017

Acknowledgement

"The paper is produced from a full study that is partly funded by the National Research Foundation (NRF). Opinions expressed in this paper and conclusions arrived at are those of the authors and are not necessarily to be attributed to the National Research Foundation."

\section{Introduction}

Liquor manufacturers and distributors refer to the township market as the "main market", resulting from the high level of business activity when compared to their counterparts in the central business district (CBD) or urban suburbs. The liquor industry has proved to be a significant player in the economy especially in job creation and thus proving to be stable with an estimated contribution to the economy of R93.2 billion in 2009/10 from the formal sectors of manufacturing and retail (Truen et al., 2011). In addition, the industry has shown significant growth of R30 billion annually (Clare et al., 2004).

Liquor is regarded as a dangerous substance, hence the high regulation of the industry globally. The South African liquor industry has had even greater issues resulting from the apartheid era, which enforced racial inequalities in terms of access to liquor, and in the regulatory conditions, which encouraged the economic isolation of many sectors of this industry (Truen, et. al 2011). This explains the reason the industry is governed by strict regulations, which include licensing of all premises that deal with the sale of liquor (South Africa, 2004).

Small, micro and medium enterprises' (SMMEs) high failure rate is still a concern globally, as SMMEs are believed to be the drivers of the economy especially regarding employment creation (Brink et al., 2003; Van Tonder \& Van Scheers, 2011; Islam et al., 2011; Chiliya \& Roberts-Lombard, 2012). In the case of township liquor retailers, one of the factors contributing to failure is the cancellation of liquor 
trading licenses because of not adhering to the license conditions. The Department of Trade and Industry (DTI) has expressed its commitment to supporting the liquor industry, further noting that the cancellation of liquor trading and manufacturing licenses hurts the economy (South Africa, 2012).

The focus of this paper is on the skills and knowledge requirements specific to township liquor retailing as it has been identified to be one of the critical success factors (CSFs) for SMMEs. There has been a generalisation of CSFs among SMMEs in different industries (Zwikael \& Globerson, 2006; Van Tonder et al., 2011). However, Olszak and Ziemba (2012) note that CSFs differ among industries, and among individual enterprises within a particular industry, or even within the same organisation.

The purpose of this paper is to identify the skills and knowledge critical to successfully managing a liquor retail business operating in the township market. The paper addresses the following objectives:

- to identify the skills and knowledge required to manage a business of this nature; and

- to establish methods that can be implemented as a form of support to township liquor retailers, with special focus on skills and knowledge development.

\section{Literature review}

\subsection{Township retailing}

Township refers to areas that were previously reserved for African settlement under the apartheid era laws; these include formal townships, site and service areas and informal settlements (Harrison et al., 1997). These areas were characterised by deliberate exclusion by race (Blacks, Coloureds and Indians) from mainstream economic participation and services (Sibiya, 2012). The majority of liquor retailers now operating in the township market ventured into this type of business as a means of providing for their families due to lack of employment opportunities for persons of their profile: middle-aged, unskilled and poor (Charma \& Petersen, 2010). However, while liquor manufacturers and distributors enjoy growth annually, the same cannot be said for the township liquor retailers.

The largest liquor manufacturer in South Africa, the South African Breweries, refers to the township market as the main market, referring to the level of business activity when comparing liquor retailers in the township with those in the urban areas and the CBD. The township market moves large volumes of stock from suppliers and manufacturers.

\subsection{Liquor industry legal structure}

In 1995, the South African Liquor Act No. 27 of 1989 was amended, providing for the nine new provinces and assigning powers to the provincial ministers (South Africa, 2004). The need for change in the new South Africa brought into practice the introduction of the Liquor Act No. 59 of 2003 that aims at establishing national norms and standards in order to maintain economic unity within the South African liquor industry (South Africa, 2004). For this paper, only two types of liquor licenses were selected as described below according to the Liquor Licensing Act, 1997.

- On-consumption (tavern, shebeen or night club): Liquor is to be sold to persons for consumption within the licensed premises.

- Off-consumption: Liquor is to be sold sealed to persons for consumption away from the premises.

The government has developed programmes to offer growth and sustainability support to SMMEs (DTI, 2012). However, these programmes are not specific to the liquor industry, which has a number of unique operational characteristics that differ from SMME retailers in other industries. Therefore, accurate measures of the efficiency of these programmes within Township liquor retailers are not available.

Government initiatives on compliance seem to be efficient, even though more still needs to be done. These initiatives include establishing the Liquor Act No. 59 of 2003, which requires the retailer to obtain a liquor license before they are eligible to sell liquor (Government Gazette, 2004:2). In addition, the Western Cape provincial government introduced the Western Cape Liquor Amendment Act No. 10 of 2010 that has a mandate of establishing a social and educational fund to educate the public on responsible selling and consumption of liquor. The fund also focuses on educating persons who engage in the sale and supply of liquor prior to the issue of the liquor license. 


\subsection{Critical success factors}

One of the most widely used definitions of critical success factors (CSFs) is that of Rockart (1979) who defined CSFs as "those performance factors which must receive ongoing attention of management if the organisation aims at remaining competitive". He further noted that critical success factors refer to the areas of an organisation where things must go right.

Identification of the CSFs in an organisation is vital as it allows for the early detection of possible threats to success. Baccarini and Collins (2003) have noted that critical success factors are the events or factors that contribute to the project outcomes. CSFs differ among industries, individual enterprises in a particular industry or even within the same organisation (Olszak \& Ziemba, 2012).

Part of the importance of identifying CSFs is that they can be used as tools for decision making in order to achieve set goals. However, the generalisation of CSFs among SMMEs operating in different industries (Zwikael et al., 2006; Van Tonder et al., 2011) could be having an impact on the failure rate of SMMEs; hence, a paper of this nature that is industry specific.

\section{Methodology}

\subsection{Research design}

The study was carried out using the qualitative phenomenological research design. Willis (2002, as cited by Koopman, 2015:3) points out "the aim of phenomenological research is to arrive at an accurate understanding and description of knowing the moments as they appear in the consciousness of individuals."

\subsection{Sampling and data collection}

The study sample comprised of two groups, namely industry experts and liquor retailers. A purposive sampling method was applied for the selection of participants; the goal was to select participants who operate in the township liquor industry, and thus understand the skills and knowledge critical to successfully managing a business of this nature.

\subsection{Exploratory study}

An exploratory study was conducted via in-depth semi-structured interviews with six industry experts. These experts included representatives of the provincial government (Western Cape Liquor Authority and Special Projects: Office of the Premier) and the township market sales representatives from the top three liquor manufacturers and distributors. These three companies hold about $80 \%$ by value and volume of the South African liquor market (Fieldgate et al., 2013). The purpose of the exploratory study was to develop an initial understanding of the market, and to gather data to later be used to construct the questionnaire for the liquor retailers.

\subsection{Descriptive interviews (surveys)}

A quota sample was selected from the 211 -valid liquor licenses existing in the study area (Khayelitsha and Mitchell's Plain) -- 20 businesses from each area (10 businesses from each license type per area), thus generating a sample size of 40 liquor retailers. This sample size was regarded as sufficient as it is within the range of 1 to 40 as suggested by Mason (2010) for qualitative research.

\subsection{Data collection (including questionnaire)}

Due to limited literature on the subject area of the study, the research began with an exploratory study with industry experts. The findings from the exploratory study helped to better understand the township liquor market and possible CSFs, and were then used to construct questionnaires for the liquor retailer survey. Interviews with the industry experts were audiotaped with the exception for the interviews with the provincial government representatives due to state policy.

\subsection{Data analysis}

Following the method suggested by Lee (1999: 97), data was manually coded and then reconstructed in themes according to the subject area of the study, which focused on the required skills and knowledge in township liquor retailing. 


\subsection{Validity and reliability}

An ethics clearance certificate was obtained from the Cape Peninsula University of Technology's ethics committee prior to the data collection process to ensure the ethical standards of the data collection process. Interview consent letters were signed by all the participants.

Because of limited literature on the subject area, the descriptive interview questions were constructed based on the findings from the exploratory study with industry experts. Furthermore, the researcher to ensure the accuracy of the interview and correct interpretation of the questions conducted the interviews with the liquor retailers.

\section{Results}

As the literature and exploratory study showed, education is important for the success of a small business (Chawla et al., 2010; Moorthy et al., 2012; Alkali et al., 2012). The profiling of the participants was aimed at obtaining an overview of their level of education and business skills which was deemed in line with the purpose of the paper that aims at identifying skills and knowledge required for the success of a liquor retail business operating in the township market.

It is to be noted that the study was not directed at examining whether or not personal characteristics play a role in the success of a liquor retail business, rather to describe their profile to better understand the selected sample.

\begin{tabular}{|l|c|l|c|l|c|c|c|c|c|}
\hline \multicolumn{1}{|c|}{ Gender } & No. & $\begin{array}{c}\text { Highest } \\
\text { Education }\end{array}$ & No. & Language & No. & Age & No. & $\begin{array}{c}\text { Business } \\
\text { Training }\end{array}$ & No. \\
\hline Females & 28 & Grade 4 & 1 & Afrikaans & 20 & $20-30$ & 2 & Yes & 26 \\
\hline Males & 12 & Grade 10 & 10 & IsiXhosa & 20 & $31-40$ & 3 & No & 14 \\
\hline & & Grade 11 & 4 & & & $41-50$ & 16 & & \\
\hline & & Grade 12 & 23 & & & $51-60$ & 17 & & \\
\hline & & Under-grad & 2 & & & $61-70$ & 2 & & \\
\cline { 5 - 10 } & & & & & $71+$ & 0 & & \\
\hline
\end{tabular}

Table 1: Sample Demographics

Undoubtedly, there is a relationship between education and skills (Malakwane, 2012); however, there is also a level of distinction between the two. Oxford Dictionaries (2016) refer to knowledge as information acquired about a particular subject, usually at school, while skills refer to "the ability to do something". The link between the two can best be seen as acquiring the knowledge (knowing what to do) and thus gaining the skills (ability to perform that particular task). It seems therefore that without knowledge, skill is not possible.

The highest level of formal education received by the participants as revealed by the findings is between grade 10 (10 participants) and grade 12 (22 participants).

In addition, the participants confirmed that they had some business training, mostly attending a supplier's business development programme in 2014. According to a representative from company A (an exploratory study participant), the said programme was four full days of classroom training where they were equipped with the basic business knowledge specially designed for a liquor retail business. The participants were issued with certificates of participation upon completion of the programme. However, the disadvantage of the program was that only those businesses trading directly with the supplier qualified to attend the training.

Table 2 is a representation of some challenges experienced by liquor retailers within the township market versus the skills and knowledge required in managing those challenges, as reflected by the study findings. Interestingly, these challenges appear to be known in the industry as they were identified by the industry experts in the exploratory study. Furthermore, the Department of Trade and Industries (DTI), private sector businesses, liquor manufactures and distributors have also developed programmes as means of offering support to SMMEs in general (South Africa, 2012; Verrest, 2013). Why these challenges still occur despite being well understood is uncertain; perhaps the issue lies with the format or quality of the current solution-based programmes offered? For example, Verrest (2013) maintains that most 
programmes cover micro-finance and general business training, and are not focused on a particular industry.

\begin{tabular}{|l|l|}
\hline Challenge & Skills and Knowledge required \\
\hline Crime & Operations management (asset \& risk management) \\
\hline Competition & Marketing and business management \\
\hline Lack of operating capital & Acquiring \& managing operating capital \\
\hline $\begin{array}{l}\text { Recruiting the right employee and employee } \\
\text { development/Motivation. }\end{array}$ & Human resource management \\
\hline
\end{tabular}

Table 2: Skills and knowledge required

It is evident that there is a link between the challenges experienced by the SMMEs and a lack of knowledge and skills. SMMEs can cope better with the challenges if business owners are equipped with the right skills and knowledge specific to their industry.

\subsection{Support received}

The findings show that in most cases township liquor retailers experience slow growth because of the challenges they are faced with; however, some of these challenges can be combatted with the right skills and knowledge.

Table 3 details any form of support that has been received by the businesses as a means to better manage the challenges. Even though $65 \%$ of the liquor retailers attended some form of skills and knowledge training, only $20 \%$ have received support to cope with the specific challenges. In addition, the retailers are of the opinion that there is still more to be done in order to see real improvement. Included in the table are the ideal skills and knowledge required per challenge.

\begin{tabular}{|c|c|c|c|}
\hline Challenge & Support & Comments from Retailers & $\begin{array}{l}\text { Required skills \& } \\
\text { knowledge }\end{array}$ \\
\hline Crime & $\begin{array}{l}\text { SA Police } \\
\text { Service (SAPS) }\end{array}$ & $\begin{array}{l}\text { SAPS arrived; but it was too late, as the criminals } \\
\text { had already escaped. }\end{array}$ & $\begin{array}{l}\text { Operations (asset \& } \\
\text { risk) management) }\end{array}$ \\
\hline \multirow{2}{*}{$\begin{array}{l}\text { Lack of } \\
\text { operating } \\
\text { capital }\end{array}$} & Suppliers & Supplier offered credit payment terms for stock & \multirow{2}{*}{$\begin{array}{l}\text { Acquiring and } \\
\text { management of } \\
\text { operating capital. }\end{array}$} \\
\hline & Bank & $\begin{array}{l}\text { Loan application declined due to the absence of } \\
\text { financial records or business bank account }\end{array}$ & \\
\hline $\begin{array}{l}\text { Business } \\
\text { training }\end{array}$ & Suppliers & $\begin{array}{l}\text { Not fully satisfied, the program focuses more on } \\
\text { On-consumption businesses than Off-consumption }\end{array}$ & \multirow{2}{*}{$\begin{array}{l}\text { Operations } \\
\text { management } \\
\text { (marketing and } \\
\text { business management) }\end{array}$} \\
\hline $\begin{array}{l}\text { Limited storage } \\
\text { space }\end{array}$ & Suppliers & $\begin{array}{ll}\text { - } & \text { Requested multiple deliveries per week. } \\
\text { - } & \text { Supplier provided extra mobile storage. }\end{array}$ & \\
\hline
\end{tabular}

Table 3: Summary of support received

\subsection{Critical success factors}

A comparison of the CSFs, as identified from the literature, the exploratory study and the interviews with the liquor retailers, is presented in Table 4 . Those CSFs found to be common are highlighted. In addition, it is to be noted that the CSFs are presented in the form of themes.

Since the research was conducted using the qualitative approach, the identified critical success factors were not given scores and therefore are not listed in order of importance. The purpose was for establishing similarities amongst the CSFs, where the summary was used to develop a framework that identifies the skills and knowledge deemed critical for the success of small micro and medium enterprises (SMMEs), in this case specific to township liquor retailing. 


\begin{tabular}{|c|c|c|c|}
\hline Critical Success Factor & Literature Review & Industry Experts & Liquor Retailers \\
\hline Financial Management & $\begin{array}{l}\text { - Capital Access } \\
\text { - Goal Orientation } \\
\text { - Purchasing }\end{array}$ & $\begin{array}{l}\text { - Capital Access } \\
\text { - Pricing }\end{array}$ & $\begin{array}{l}\text { - Capital Access (stock \& business } \\
\text { improvement) } \\
\text { - Transacting/Banking } \\
\text { - Budgeting for business goals }\end{array}$ \\
\hline $\begin{array}{l}\text { Human Resource } \\
\text { Management }\end{array}$ & $\begin{array}{l}\text { - Appropriate } \\
\text { human resource } \\
\text { management }\end{array}$ & $\begin{array}{l}\text { - Staff shortage - need } \\
\text { for proper staff } \\
\text { complement, }\end{array}$ & $\begin{array}{l}\text { - Getting the right calibre of } \\
\text { employees. } \\
\text { - Motivating \& developing current } \\
\text { staff. }\end{array}$ \\
\hline \multicolumn{2}{|l|}{ Operations Management } & & \\
\hline $\begin{array}{l}\text { 1. Asset \& risk } \\
\text { management }\end{array}$ & $\begin{array}{l}\text { • Inventory } \\
\text { Management }\end{array}$ & $\begin{array}{l}\text { - Crime (business } \\
\text { robbery \& customer } \\
\text { safety) }\end{array}$ & $\begin{array}{l}\text { - Crime (business robbery \& } \\
\text { customer safety) } \\
\text { - Staff theft }\end{array}$ \\
\hline 2. Marketing & $\begin{array}{l}\text { - Image Management } \\
\text { - Social network } \\
\text { - Technology } \\
\text { - Industry trends }\end{array}$ & $\begin{array}{l}\text { - High competition } \\
\text { (off-consumption } \\
\text { threatened by entry } \\
\text { of major retailers into } \\
\text { township market) }\end{array}$ & $\begin{array}{l}\text { - High competition (off-consumption } \\
\text { threatened by entry of major } \\
\text { retailers into township market) }\end{array}$ \\
\hline 3. Compliance & $\begin{array}{l}\text { - Legality (not } \\
\text { specified) }\end{array}$ & $\begin{array}{l}\text { - Liquor license } \\
\text { trading conditions. }\end{array}$ & $\begin{array}{l}\text { - Liquor license trading conditions } \\
\text { - Off-consumption - reduced trading } \\
\text { hours } \\
\text { - Annual liquor license renewal fee } \\
\text { - Compliance requirements (fire } \\
\text { extinguishers, zoning certificate, } \\
\text { noise exemption certificate) }\end{array}$ \\
\hline
\end{tabular}

Table 4: Comparison of critical success factors

What is evident from the above comparison is that CSFs can be recognised as acquiring the right skills and knowledge specific to that particular industry. Figure 1 is therefore a representation of the CSFs in township liquor retailing

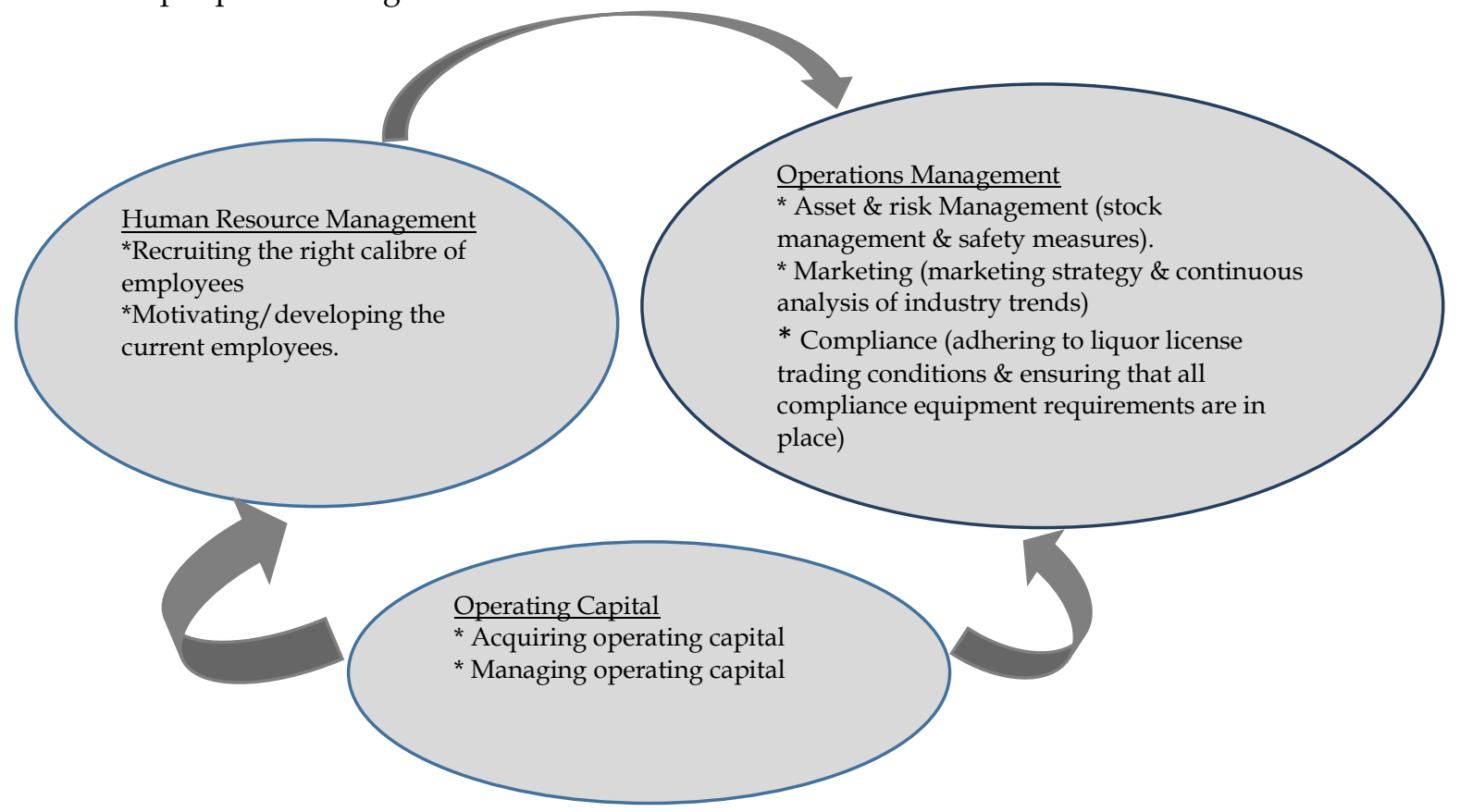

Figure 1: Critical success factors framework for township liquor retailing

\section{Discussion}

Money, time and resources are lost annually as a result of failed business ventures caused mostly by avoidable mistakes (Brink et al., 2003). Knowledge and skills can be regarded as CSFs in SMMEs in 
South Africa (Brink et al., 2003; Van Tonder et. al., 2011; Islam et al., 2011; Chiliya et. al, 2012). Furthermore, the findings revealed that even though the majority of the participants are aware of the existence of organisations, institutions and government departments offering support to businesses of this nature, access to information is still a barrier (Alkali et al., 2012). Better management of the CSFs is dependent on acquiring the necessary industry specific skills and knowledge as shown in the framework in Figure 1, the components of which are now described as they apply to township liquor retailing.

\subsection{Operating capital management}

This section explains the components of operating capital as an identified CSF.

The findings show that a business of this nature can be started with minimal capital; however, as the business grows, operating capital becomes more of a challenge, frequently resulting in the inability to meet increased consumer demand and ever changing industry trends. This agrees with the finding by Chawla et al. (2010) and Alkali et al. (2012) who discovered that ability to acquire credit and sound financial management play a role in the success of a business. In the context of this study, the critical factors under operating capital are for business premises improvement and capital stock. Therefore, access and ability to acquire credit is vital.

According to the findings from the exploratory study (interviews with liquor manufacturers and brand distributors), even though the liquor retailers benefit from the advantages of economies of scale, poor financial management skills remains a concern as there is no knowledge about re-investing the resultant savings towards business growth and sustainability.

\subsection{Human resource management}

Getting the right calibre of employees: According to the findings, potential candidates for employment compare SMMEs with the larger corporate businesses in terms of benefits and salaries. In a case where these expectations are not met, the level of productivity by the employee decreases. In order for these businesses to realise success, they require motivated employees who understand that the nature and size of the enterprise will influence what a candidate can be offered as far as the salary package is concerned.

\subsection{Operations management}

The following list is comprised of the items that constitute the operations management CSFs in township liquor retailing.

a) Asset and risk management: Liquor retailers operating in the townships are continuously faced with the challenge of crime, as they are frequent targets of criminal activities. This is not a surprise as the crime rate, especially in the Western Cape, has shown a significant increase when comparing the 2013/2014 and 2014/2015 fiscal years (South African Police Service, 2015). The retailers interviewed are of the opinion that cash and the type of merchandise (liquor) they deal with are of high value, thus making them targets for robberies. In addition, consumers are also at risk of crimes as they are usually under the influence of liquor after spending time at the outlets.

Industry experts (suppliers) from the exploratory study also agreed on the issue of crime as a challenge. They further pointed out that once liquor retailers get robbed, the supplier also suffers (e.g. lose sales and money in the case where the liquor retailer bought stock on credit).

b) Marketing management: Considering the high rate of unemployment in the country, especially in the townships, the entry of big retailers in the township market was thought to be of great benefit. However, the findings reveal that this is a significant factor threatening the growth of the traditional liquor retail industry. This is because large retailers escalate the competition, particularly for the offconsumption liquor retailers who are in close proximity to these new large retailers (Madlala, 2016).

On the other hand, on-consumption liquor retailers are finding it difficult to cope with the fast changing consumer and market trends. This once again can be linked to the lack of skills and knowledge.

c) Compliance: The liquor industry can be regarded as highly regulated, which stems from the dangers of the substance (Liquor Act No. 59 of 2003 and Western Cape Liquor Act No. 10 of 2010). Liquor retailers are continually faced with law amendments - the cost of the requirements to be compliant puts a strain on these small businesses. Some liquor retailers lose their trading licenses as a result of not adhering to the license conditions. According to the retailers interviewed, the issue is not one of 
compliance, but rather of the cost attached with complying. Examples mentioned include the R3000 annual liquor license renewal fee, and fire extinguisher installation and service fees. Some industry role players have noted the threat caused by cancellation of trading licenses. The DTI (2012) has expressed its support for the industry and noted that the cancellation of trading licenses is detrimental to the economy.

\section{Implications}

\subsection{Implications for industry}

Financial institutions

There is a potential untapped market that could be of benefit to the financial institutions through credit and investment services and those that offer bookkeeping, accounting and tax services.

\section{Government}

The contribution made by the industry cannot be measured with precision, as the majority of these businesses are informal. Furthermore, although the businesses are paying their annual license renewal fees at the Liquor Authority, each one's tax compliance is undetermined as there are no financial statements or tax clearance certificates available.

\section{Liquor retailers}

The lack of skills and knowledge is not only affecting the liquor retailers' operations, but also their access to information. Limited knowledge means that they are unable to take full advantage of available support opportunities that could escalate their businesses' growth and success. Charman and Petersen (2010) point out that if government does not formulate a strategy to transform shebeens and taverns into formalised sustainable businesses, then the government might be destroying the opportunity of creating a class of black entrepreneurs with whom it may partner in reducing the harmful effects of irresponsible trading and consumption of liquor. In addition, the research questions the efficiency of the programmes developed by the DTI, which are aimed at supporting liquor retailers and SMMEs at large. Furthermore, the inefficiency could also be because of the "one-size fits all" approach (generalized approach for SMMEs across all industry) whilst literature points out those CSFs differ from industry to industry.

\section{Manufacturers and brand distributors}

The manufacturers and brand distributors are unable to gain maximum returns by investing in the township liquor retail industry. This is mainly influenced by the insufficient business knowledge and inadequate skills, which determine the success of the trade agreement between the two parties (liquor retailers and manufacturers and/or brand distributors).

\subsection{Implications for academia}

There is limited academic literature on skills and knowledge that are specific per industry; particularly township liquor retailing. The implementation of a general approach across industries could be a contributor to the high failure of the SMME liquor retailers, particularly considering the low skills and knowledge profile of the majority of SMMEs. This study has highlighted this problem and will hopefully encourage further academic research in the township liquor retail market.

\section{Limitations and recommendations \\ 7.1 Limitations}

It is to be noted that the research was conducted only in a few selected townships - it is therefore not a representation of all township markets. Care should thus be taken in trying to apply these findings to other township areas.

Furthermore, due to the low education profile of the liquor retailers, language was a barrier, especially with the participants from Khayelitsha. The interviews took longer than predicted as the researcher had to translate the questions into IsiXhosa (the local language). This slow process could have resulted in respondents becoming bored and not giving carefully considered answers.

\subsection{Further research}

Although the primary objective of the paper was achieved, the following areas were identified as knowledge gaps for future research that could be of benefit to both industry and academia.

- An investigation into the effectiveness of the current support programmes designed for liquor retailers; and 
- An investigation into the change in attitudes (from unproductive to productive entrepreneurs) once entrepreneurs are equipped with adequate skills and knowledge for managing a profitable and sustainable liquor retail business.

\subsection{Recommendations}

The following recommendations are suggested by the researcher based on the findings and literature.

\subsubsection{Business skills training.}

Rather than the numerous separate programmes offered by government, manufacturers and brand distributors, a joint venture would be more efficient. Furthermore, considering the education level of the majority of these entrepreneurs, a more practical and customised approach would be better. The current programmes, according to the industry experts interviewed, adhere to a classroom concept, so perhaps an exhibition style concept, with interactive demonstrations and practical hands-on learning activities would yield better results. Industry experts could present solutions tailored for liquor retail businesses at a one day exhibition style event. The target audience would be liquor retailers who will leave better equipped with skills, knowledge and tailored solutions provided by industry experts through face-to-face consultations in their preferred languages.

\subsubsection{The use of Massive Open Online Colleges (MOOCs)}

As the world embraces the Massive Open Online College (MOOCs) concept, Africa also possesses such facilities, with the University of South Africa and the University of the Witwatersrand, Johannesburg at the forefront of the deployment of MOOC portals (Marshall, 2016).

Such MOOCs have the potential to become one of the solutions to the shortage of knowledge and skills amongst Township liquor retail owners. It may however mean that in order for the MOOCs concept to be efficient, language barriers and internet connection costs will need to be addressed. It is suggested that the industry, in the form of government, manufacturers and brand distributors, should liaise with these universities to investigate how best to apply the MOOC concept for township liquor retailers.

\section{Conclusion}

The importance of acquiring the right skills and knowledge is evident from both the findings and literature. Notwithstanding the investment made by government and private sector to support the growth of the SMMEs through skills and knowledge development programmes, the study revealed the importance of re-structuring these programs into a more industry specific format. Considering the education profile of these township liquor retailers, perhaps a more practical approach would be ideal rather than the classroom set-up. Emphasis should also be placed on the language spoken per area. There is still more to be done in order for these businesses to be fully able to participate in all economic activities.

\section{References}

Agupusi, P. (2007), Small business development and poverty alleviation in Alexandra, South Africa, $2^{\text {nd }}$ Meeting of the ECINEQ Society, 12-14 July, Berlin.

Alkali, M., Isa, A.H.M, \& Baba, H. (2012), "A conceptual model of factors affecting business performance among the manufacturing sub-sector of small business enterprises in Nigeria (Bauchi state)", Interdisciplinary journal of contemporary research in business, 4(5), 367-370.

Baccarini, D.\& Collins, A. (2003), "Critical success factors for projects", in Brown, A. (ed), Surfing the Waves: Management Challenges; Management Solutions, Proceedings of the 17th ANZAM Conference, 2-5 December, Fremantle, Western Australia

Brink, A., Cant, M. \& Ligthelm, A. (2003), Problems experienced by small businesses in South Africa, $16^{\text {th }}$ Annual Conference of Small Enterprise Association of Australia and New Zealand, Ballarat, 28 September - 1 October.

Charman, A \& Petersen, L. (2010), The inconvenient truth of the Western Cape Liquor Act, Sustainable Livelihoods Foundation.

Chawla, K.S., Khanna, D. \& Chen, J. (2010), "Are small business critical success factors same in different countries?", SIES Journal of Management, 7(1), 1-12. 
Chiliya, N. \& Roberts-Lombard, M. (2012), "Impact of level of education and experience on profitability of small grocery shops in South Africa", International Journal of Business Management and Economic Research, 3(1),462-470.

Clare, K., Ramatapa, E. \& Currin, B. (2004), Study of the liquor industry in South Africa, Reality Research Africa Report prepared for the Department of Trade and Industry, March, Johannesburg.

Fieldgate, I., Jeffrey, R., Madinane, M., Ebrahim, Y., Soobyah, L. \& Jordaan, J. (2013), “Economic impact of an advertising ban on alcoholic beverages for industry association for responsible alcohol use", Econometrix, Johannesburg.

Harrison, P., Todes, A. \& Watson, V. (1997), “Transforming South Africa's cities: Prospects for the economic development of urban townships", Development SouthernAfrica, 14(1), 43-60.

Islam, A., Khan, M.A., Obaidullah, A.Z.M. \& Allam, M.S. (2011), "Effect of entrepreneur and firm characteristics on the business success of Small and Medium Enterprises (SMEs) in Bangladesh", International Journal of Business and Management, 6(3), 289-296.

Koopman, O. (2015), "Phenomenology as a potential methodology for subjective knowing in science education research", Indo-Pacific Journal of Phenomenology, 15(1), 1-10.

Lee, T.W. (1999), Using Qualitative Methods in Organizational Research, Sage, Thousand Oaks.

Madlala, T.T. (2016), Do large retailers displace small informal retailers? The case of a Pick $n$ Pay store in KwaMashu, Durban, South Africa, Paper read at $12^{\text {th }}$ International Scientific Conference on Economic \& Social Development, Bangkok, 18-20 Feb.

Mason, M. (2010), "Sample size and saturation in PDH studies using qualitative interviews", Forum Qualitative Sozialforschung/Forum: Qualitative Social Research, 11(3), Art. 8.

Malakwane, C.T. (2012), Economic and social effects of unemployment in South Africa: Prospects for the future, Tshwane University of Technology, June.

Marshall, J. (2016), "MOOCs have a massive potential market in Africa", University World News, 1 July. http:/ / www.universityworldnews.com/article.php?story=20160630195218201

Moorthy, K.M., Tan, A., Choo, A., Wei, C.S., Ping, J.T.Y. \& Leong T.K. (2012), “A study of factors affecting the performance of SMEs in Malaysia", International Journal of Academic Research in Business and Social Sciences, 2(4), 224-236.

Olszak, C.M \& Ziemba, E. (2012), “Critical success factors for implementing Business Intelligence Systems in Small and Medium Enterprises on the example of Upper Silesia, Poland", Interdisciplinary Journal of Information, Knowledge, and Management, 7(12), 129-150.

Oxford Dictionaries (2016), English Oxford Living Dictionaries, https://en.oxforddictionaries.com/.

Rockart, JF. (1979), "Chief executives define their own data needs", Harvard Business Review, 57(2), 81-93.

Sibiya, P.N. (2012), Gentrification in the Former Black Townships: The Case of Soweto in South Africa, Unpublished Master's dissertation, University of Witwatersrand, Johannesburg.

South Africa. (2004), “Liquor Act 2003. Notice 59 of 2003”, Government Gazette, 466 (26294), 1-26 April 26.

South Africa. (2012), Cancellation of liquor licences hurts the economy and job creation, Department of Trade and Industry, 6 June.

http//www.info.gov.za/speech/DynamicAction?pageid=461\&sid=28156\&tid=71694

South African Police Service. (2015), Crime Statistics Report 2014/2015, South African Police Service, Pretoria.

Truen, S., Ramkolowan, Y., Corrigall, J. \& Matzopoulos, R. (2011), Baseline study of the liquor industry including the impact of the National Liquor Act 59 of 2003, DNA Economics, Pretoria.

Van Tonder, E \& Van Scheers, L. (2011), "Surviving the business life cycle: a theoretical framework for independent financial advisers", Journal of Contemporary Management, 8, 567-590.

Verrest, H. (2013), "Rethinking micro entrepreneurship and business development programmes: Vulnerability and ambition in low-income urban Caribbean households", World Development, 47, 5870 .

Zwikael, O \& Globerson, S. (2006), "From critical success factors to critical success processes", International Journal of Production Research, 44(17), 3433 -3449. 